\title{
Spectinomycin hydrochloride (Trobicin) in the treatment of gonorrhoea
}

\section{Observation of resistant strains of Neisseria gonorrhoeae}

\author{
ALICE REYN*, H. SCHMIDT†, M. TRIERł, AND M. W. BENTZON§ \\ From the ${ }^{\star} W H O$ International Reference Centre for Gonococci, the Neisseria Department, and the §Biostatistics \\ Department, Statens Seruminstitut, Copenhagen, †Odense University Hospital, and the $\ddagger$ Public Health Venereal \\ Disease Clinic, Odense, Denmark
}

Treatment of gonorrhoea with penicillin injections is still considered to be the method of choice, as penicillin is both non-toxic and highly effective when given in suitable doses. However, since about 5 per cent. of patients attending venereal disease clinics are allergic to penicillin (Epstein, 1959; Willcox, 1959; Schmidt, 1961), it is important to have several alternatives available. Various injectable antibiotics other than penicillin can be used, including streptomycin and the tetracyclines, but many strains of gonococci are completely resistant to streptomycin or less sensitive to the tetracyclines.

Oral treatment of sexually transmitted diseases has several drawbacks. Patient-to-patient variations in blood levels tend to be greater than in those treated by injection (Schmidt, Roholt, and Larsen, 1967), and patients cannot always be trusted to take their doses correctly. Finally, the patient may be tempted to share his drug with his infected partner, so that both receive inadequate therapy.

An injectable aminocyclitol antibiotic, spectinomycin, was isolated in 1960 from Streptomyces spectabilis, and spectinomycin sulphate appeared to be effective in the treatment of gonorrhoea (Laird and Taylor, 1962; Willcox, 1963; Sparling, Yobs, Billings, and Hackney, 1966; Tiedemann, Hackney, and Price, 1965). Recently, the more soluble dihydrochloride salt of spectinomycin has become available commercially in the United States.

The aim of the present study was:

Received for publication September 7, 1972

This study was supported by grants from the World Health Organization

Requests for reprints should be addressed to: Dr. Alice Reyn, The Neisseria Department, Statens Seruminstitut, Amager Boulevard 80, DK-2300 Copenhagen S, Denmark

$\star$ Trobicin (®) was supplied to the authors by UPJOHN (a) To examine the clinical effect of spectinomycin hydrochloride ${ }^{\star}$ in patients with acute uncomplicated gonorrhoea;

(b) To test the antibiotic sensitivity of the gonococcal strains isolated from the patients before and after treatment;

(c) To compare the antibiotic sensitivity of gonococcal strains isolated from patients and their contacts.

\section{Material and methods}

Altogether 136 strains of $N$. gonorrhoeae were isolated from 113 patients, 61 males and 52 females; 134 were pretreatment isolates and two were post-treatment isolates from one patient. Methylene blue stained smears from the urethra in males and from the urethra and cervix in females were examined. Where intracellular diplococci were demonstrated, the patients were treated immediately with Trobicin. In the other cases, Trobicin was given after $N$. gonorrhoeae had been found by culture. Specimens of secretion were taken on charcoal impregnated cotton-wool swabs from the urethra, cervix, and rectum when possible. The swabs were transported in solid Stuart's medium (Reyn, Korner, and Bentzon, 1960; Ringertz, 1960) to the Neisseria Department, Statens Seruminstitut, Copenhagen, for culture and determination of antibiotic susceptibility.

The dosage of Trobicin was $2 \mathrm{~g}$. (ml.) intramuscularly in males and $4 \mathrm{~g}$. (ml.) intramuscularly in females. The trial was carried out early in 1971.

Sensitivity to penicillin, tetracycline, dihydrostreptomycin, and spectinomycin dihydrochloride pentahydrate was examined by the plate-dilution method. The results are given as 50 per cent. inhibitory concentrations $\left(\mathrm{IC}_{50}\right)$ (Reyn, Bentzon, and Ericsson, 1963). Since most of the strains received from Odense were sensitive to penicillin, the series was supplemented by 37 strains 
known to be less sensitive to penicillin taken at random from those sent to the Neisseria Department for sensitivity determination in 1971.

\section{MICROSCOPY V. CULTURE}

Intracellular diplococci were found by microscopy in 56 (92 per cent.) of 61 males with acute, uncomplicated gonorrhoea. The remaining five cases were diagnosed by culture, four from the urethra and one from the rectum. Gonorrhoea was diagnosed by microscopy in 35 (61 per cent.) of 52 female cases. All cases diagnosed by microscopy were confirmed by culture. In females, gonococci were found more frequently in specimens from the cervix than in those from the urethra.

\section{CULTURES FROM DIFFERENT SITES IN FEMALES}

Table I shows that gonococci were cultured from the urethra in 37 (71 per cent.) cases, from the cervix in 50 (96 per cent.) cases, and from the rectum in 20 (37 per cent.) cases. In one patient gonococci were cultured from the rectum only, and in another from the urethra only.

TABLE I Cultures from 52 female patients with gonorrhoea

\begin{tabular}{|c|c|c|c|}
\hline Urethra & Cervix & Rectum & $\begin{array}{l}\text { No . of } \\
\text { patients }\end{array}$ \\
\hline 0 & 0 & 0 & 0 \\
\hline+ & 0 & 0 & 1 \\
\hline+ & + & 0 & 22 \\
\hline+ & + & + & 14 \\
\hline 0 & + & + & 5 \\
\hline 0 & + & 0 & 9 \\
\hline 0 & 0 & + & 1 \\
\hline+ & 0 & + & 0 \\
\hline
\end{tabular}

\section{Results of treatment}

Four of the 113 patients were not examined after treatment. Four of the remaining 109 patients were examined only once, a week after treatment; all had negative cultures and were symptomless. Of the remaining 105 patients who were examined at least twice after treatment (Table II), only one had positive cultures. The cure rate was thus about 99 per cent. None of the patients complained of pain from the injections, nor were any side-effects observed.

\section{TABLE II Number of post-treatment tests}

\begin{tabular}{lllrrrr}
\hline Number of cultures & 0 & 1 & 2 & 3 & 4 & 5 \\
Number of patients & 4 & 4 & 20 & $80^{\mathrm{a}}$ & 3 & 2 \\
\hline
\end{tabular}

ane of these was examined after treatment with tetracycline (Table III)

The patient who was not cured, and who denied the possibility of re-infection, was a male who was re-examined 1 month after treatment. Gonococci were demonstrated in urethral material by both microscopy and culture. Since the result of the susceptibility testing to Trobicin was not available at that time, he was re-treated with $2 \mathrm{~g}$. Trobicin, and 2 weeks later gonococci were again demonstrated by microscopy and culture. $\mathrm{He}$ was treated and cured by tetracycline, three negative cultures being obtained after this treatment. For practical reasons, only routine sensitivity testing (to penicillin, streptomycin, and tetracycline) was performed when the positive cultures were obtained. Testing to Trobicin was postponed until later. Therefore, it was not realized until then that the sensitivity of the patient's gonococci, which was high $\left(\mathrm{IC}_{50}: 7.5 \mu \mathrm{g} . / \mathrm{ml}\right.$.) before treatment, was very low in the two cultures taken 1 month and 6 weeks after treatment. It will be seen from Table III that the $\mathrm{IC}_{50}$ values to penicillin, streptomycin, and tetracycline of two gonococcal strains isolated after treatment were very similar.

TABLE III Antibiotic susceptibility of strains isolated from the patient who was not cured by Trobicin $\left(I C_{50} \mu g . / m l.\right)$

\begin{tabular}{|c|c|c|c|}
\hline Penicillin & Streptomycin & Tetracycline & Trobicin \\
\hline $\begin{array}{l}0.005 \\
0.005 \\
0.005\end{array}$ & $\begin{array}{l}\leqq 25 \cdot 0 \\
\leqq 25 \cdot 0 \\
\leqq 25 \cdot 0\end{array}$ & $\begin{array}{l}0 \cdot 14 \\
0 \cdot 28 \\
0 \cdot 20\end{array}$ & $\begin{array}{r}7 \cdot 5 \\
\geqq 42 \cdot 0^{\mathrm{a}} \\
\geqq 168 \cdot 0^{\mathrm{a}}\end{array}$ \\
\hline
\end{tabular}

${ }^{\mathrm{a}} \mathrm{MIC}: \geqq 480 \mu \mathrm{g}$. on retesting

\section{Antibiotic sensitivity}

\section{(a) Inhibitory values}

134 pre-treatment isolates from a total of 113 patients ('Odense strains') were tested against Trobicin, penicillin, dihydrostreptomycin, and tetracycline by the plate-dilution technique. The results were recorded as $\mathrm{IC}_{50}$ values in $\mu \mathrm{g} . / \mathrm{ml}$. Two or three isolates were obtained from seventeen patients, but only the results with the first isolates are included in this report.

It was possible to estimate the $\mathrm{IC}_{50}$ values by means of the Kärber method (Reyn and others, 1963 ) in only 107 of the first pre-treatment isolates. The remaining six strains did not grow satisfactorily on the control medium without antibiotics, the reproducibility on repeated testing was relatively poor, and the strains were inhibited by low concentrations of all the antibiotics employed.

The $\mathrm{IC}_{50}$ values of the pre-treatment isolates ranged from 2.2 to $12.6 \mu \mathrm{g}$. $/ \mathrm{ml}$. Trobicin, forming a one-peak distribution with the highest number of strains at about $7 \mu \mathrm{g} . / \mathrm{ml}$. The $\mathrm{IC}_{50}$ values for 36 of the 37 supplementary strains ranged from 6.3 
TABLE IV Distribution of $I C_{50}$ values of Trobicin in 'Odense strains', and supplementary strains in relation to the susceptibility of dihydrostreptomycin

\begin{tabular}{|c|c|c|c|c|c|c|c|}
\hline \multirow{3}{*}{$\begin{array}{l}\text { Trobicin } \\
(\text { IC } \\
\mu g . / m l .)\end{array}$} & \multicolumn{3}{|c|}{ Pre-treatment strains from Odense } & \multicolumn{3}{|c|}{ Supplementary strains ${ }^{\mathrm{b}}$} & \multirow{3}{*}{$\begin{array}{l}\text { Grand } \\
\text { Total }\end{array}$} \\
\hline & \multicolumn{2}{|c|}{ Dihydrostreptomycin ${ }^{\mathrm{a}}$} & \multirow[b]{2}{*}{ Total } & \multicolumn{2}{|c|}{ Dihydrostreptomycin } & \multirow[b]{2}{*}{ Total } & \\
\hline & Sensitive & Resistant & & Sensistive & Resistant & & \\
\hline $\begin{array}{l}2 \cdot 2 \\
2 \cdot 7 \\
3 \cdot 2\end{array}$ & $\begin{array}{l}4 \\
0 \\
0\end{array}$ & & 4 & & & & 4 \\
\hline $3 \cdot \overline{8}$ & 7 & & 7 & & & & 7 \\
\hline $6 \cdot 3$ & 25 & 1 & 26 & 3 & 5 & 8 & 34 \\
\hline 7.5 & 22 & 3 & 25 & & 6 & 6 & 31 \\
\hline 8.9 & 16 & & 16 & 1 & 17 & 18 & 34 \\
\hline $10 \cdot 6$ & 8 & 2 & 10 & & 4 & 4 & 14 \\
\hline $12 \cdot 6$ & 2 & & 2 & & $i$ & $i$ & 3 \\
\hline Total & 100 & 7 & 107 & 4 & 33 & 37 & 144 \\
\hline
\end{tabular}

aSensitive: $\mathrm{IC}_{50} \leqq 25 \mu \mathrm{g} . / \mathrm{ml}$. Resistant: $\mathrm{IC}_{50}>25 \mu \mathrm{g} . / \mathrm{ml}$.

bAll less sensitive to penicillin

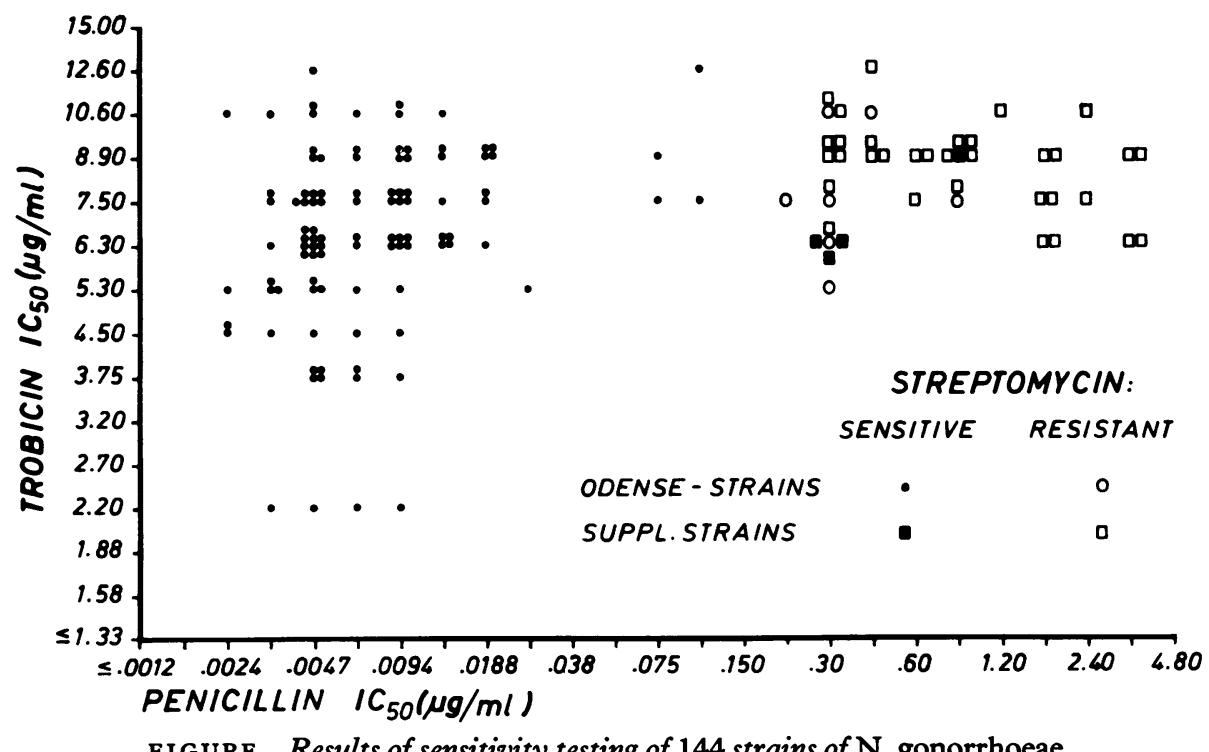

to $10 \mu \mathrm{g} . / \mathrm{ml}$. only, with the highest number at about $9 \mu \mathrm{g} . / \mathrm{ml}$. (Table IV, above). In the preliminary screening experiments of possible $\mathrm{IC}_{50}$ values which might be found, one random strain from Copenhagen needed more than $480 \mu \mathrm{g} . / \mathrm{ml}$. to give complete inhibition and thus was just as resistant as the two post-treatment isolates obtained from the only patient who was not cured. These three strains were tested repeatedly with Trobicin.

The Fig. shows the $\mathrm{IC}_{\mathbf{5}}$ values for Trobicin plotted against those for penicillin; the values for the two antibiotics show a weak positive correlation. The usual (Reyn, Korner, and Bentzon, 1958; Reyn, 1961) positive correlation between decreased sensitivity to penicillin and resistance to streptomycin can be seen, and the Trobicin values in the strains resistant to streptomycin are also higher than in those sensitive to that drug. Furthermore, it was observed that the $\mathrm{IC}_{50}$ values for Trobicin and tetracycline are correlated. This was to be expected, since a strong positive correlation between the $\mathrm{IC}_{30}$ values of penicillin and tetracycline had been demonstrated previously (Reyn and others, 1958; Reyn, 1961; Reyn, 1963). 
TABLE V Sensitivity patterns in different series of gonococcal strains

\begin{tabular}{|c|c|c|c|c|}
\hline Strain & $\begin{array}{l}\text { Number } \\
\text { of strains }\end{array}$ & $\begin{array}{l}\text { Penicillin } \\
\text { less sensitive }\end{array}$ & $\begin{array}{l}\text { Streptomycin } \\
\text { resistant }\end{array}$ & $\begin{array}{l}\text { Tetracycline } \\
\text { less sensitive }\end{array}$ \\
\hline $\begin{array}{l}\text { Pre-treatment strains from Odense } \\
(\text { S and D strains })^{\mathrm{a}} \\
\text { (February to May, 1971) }^{\text {(Febar }}\end{array}$ & 107 & $11(10 \cdot 3)^{\mathrm{b}}$ & $7(6.5)$ & $3(2 \cdot 8)$ \\
\hline $\begin{array}{l}\text { S strains from the whole of Denmark } \\
\text { (First half of 1971) }\end{array}$ & 2647 & $825(31 \cdot 2)$ & $652(24 \cdot 6)$ & $262(9.9)$ \\
\hline $\begin{array}{l}\text { D strains from the whole of Denmark } \\
\text { (July-Sept. 1971) }\end{array}$ & 205 & $39(19 \cdot 0)$ & $26(12 \cdot 7)$ & $10(4 \cdot 9)$ \\
\hline $\begin{array}{l}\text { Half } S+\text { half } D \text { strains from the } \\
\text { whole of Denmark } \\
\text { (First half of } 1971 \text { ) }\end{array}$ & & $(25 \cdot 0)$ & $(18 \cdot 7)$ & $(7 \cdot 4)$ \\
\hline
\end{tabular}

aS strains: strains sent in with a request for sensitivity determination

D strains: strains sent in for diagnostic purposes only

${ }^{b}$ Figures in brackets $=$ percentages

Penicillin; less sensitive $\quad$ IC $_{50} \geqq 0.053 \mu \mathrm{g} . / \mathrm{ml}$.

Streptomycin; resistant $\quad \mathrm{IC}_{50}>25 \mu \mathrm{g} . / \mathrm{ml}$.

Tetracycline; less sensitive $\quad \mathrm{IC}_{50} \geqq 1 \cdot 13 \mu \mathrm{g} . / \mathrm{ml}$.

Table $\mathrm{V}$ shows a comparison of the incidence of 'Odense strains' less sensitive to penicillin, resistant to streptomycin, or less sensitive to tetracycline, with the incidence in two categories of strains derived from the whole of Denmark, viz. S and D strains. S strains ('sensitivity strains') are received with a request for sensitivity determination, whereas D strains ('diagnostic strains)' are sent in for diagnostic purposes only.

The 'Odense strains' comprise both $S$ and $D$ strains. During recent years, the distribution of $S$ and D strains observed by the Neisseria Department for the whole of Denmark has been about fiftyfifty. Provided that the 'Odense strains' consist of equal numbers of what under 'average circumstances' would be either S or D strains, the expected precentages would be as shown in the lowest line of Table V.

It will be seen that the percentages of strains less sensitive to penicillin and tetracycline or resistant to streptomycin among the 'Odense strains' are lower than for the $S$ and $D$ strains from the whole country and are also lower than the estimated percentages given of an equal number of $\mathrm{S}$ and $\mathrm{D}$ strains. This indicates that the gonococcal strains from Odense are generally more sensitive to penicillin, etc., than those from the whole of Denmark. Strains from the capital, Copenhagen, predominate in the latter group.

\section{(b) Reproducibility}

The variation of the $\log \mathrm{IC}_{50}$ values was examined for repeated samples from seventeen individual patients (generally not more than one week between samples) and for samples from the 24 pairs of contacts in the material from Odense. The standard deviaitons of differences between duplicate determinations $\left(s_{d}\right)$ are given in Table VI.

The estimates tally well with similar estimates obtained previously (Reyn and Bentzon, 1963). It should be emphasized, however, that the range of $\mathrm{IC}_{50}$ values observed for Trobicin is narrow in relation to that observed for penicillin. Therefore, the $\mathrm{IC}_{50}$ values of Trobicin observed do not permit any decision to be made as to identity or nonidentity between two consecutive strains isolated

TABLE VI Survey of standard deviations $\left(\mathrm{s}_{\mathrm{d}}\right)$ of $\log I C_{50}$ values obtained in different materials

\begin{tabular}{|c|c|c|c|c|c|}
\hline \multirow{2}{*}{\multicolumn{2}{|c|}{ Antibiotic }} & \multirow{3}{*}{$\begin{array}{l}1962 \\
\text { Schmidt and Larsen } \\
\text { Contacts }\end{array}$} & \multirow{3}{*}{$\begin{array}{l}1963 \\
\text { Reyn and Bentzon } \\
\text { Repeated examinations }\end{array}$} & \multicolumn{2}{|c|}{ Present study } \\
\hline & & & & \multirow{2}{*}{$\frac{\text { Contacts }^{\mathrm{a}}}{0 \cdot 11}$} & \multirow{2}{*}{$\frac{\text { Repeated examinations }}{0.08}$} \\
\hline Spectinomycin & 2-fold dil. steps & & & & \\
\hline \multirow{2}{*}{ Penicillin } & 2-fold dil. steps & & $0 \cdot 20$ & & \\
\hline & 4-fold dil. steps & $0 \cdot 23$ & $0 \cdot 25$ & $0 \cdot 24$ & $0 \cdot 27$ \\
\hline \multirow{2}{*}{ Tetracycline } & 2-fold dil. steps. & & $0 \cdot 15$ & & \\
\hline & 4-fold dil. steps & 0.15 & & $0 \cdot 14$ & $0 \cdot 15$ \\
\hline
\end{tabular}

aTested on the same day 
from one patient, or between strains from two or more sexual partners, as proposed by Schmidt and Larsen (1962) with respect to penicillin and tetracycline.

\section{Discussion and conclusions}

Cornelius and Domescik (1970) found no failures among 108 men treated with $2 \mathrm{~g}$. spectinomycin hydrochloride and only four among 100 women treated with either 2 or $4 \mathrm{~g}$. Labowitz, Porter, and Holloway (1970) found that 80 per cent. of 55 patients followed-up after treatment were cured. Platts (1970) reported two failures in 56 patients. Pedersen, Wiesner, Holmes, Johnson, and Turck (1972) compared the effect of 2 and $4 \mathrm{~g}$. spectinomycin with that of procaine penicillin in three groups of similar size and with the same proportion of males and females. After re-examination within 7 days after treatment, the failure rates in males were 17 per cent. for 2.4 m.u. procaine penicillin, and 0 per cent. for $2 \mathrm{~g}$. and 3.4 per cent. for $4 \mathrm{~g}$. spectinomycin hydrochloride. In females, the failure rates were 13 per cent. for $4.8 \mathrm{~m}$.u. procaine penicillin and 4.3 per cent. for $2 \mathrm{~g}$. and 4.7 per cent. for $4 \mathrm{~g}$. spectinomycin hydrochloride. Duncan, Holder, Roberts, and Knox (1972) compared the effect of spectinomycin hydrochloride with that of penicillin. Cure rates were over 90 per cent. after both forms of treatment. Schroeter and Lucas (1972) reported 100 per cent. cure rates in both males and females observed for 7 days (or 92 per cent. if possible re-infection was included). The present result (99 per cent. cure rate) is in agreement with the favourable effect reported above. However, a post-treatment isolate resistant to $480 \mu \mathrm{g} . / \mathrm{ml}$. of Trobicin was recovered twice from the one patient who was not cured by that drug.

It was found that about 5 per cent. of the cultures isolated from the patients treated with Trobicin did not grow well on the medium employed. It was therefore impossible to evaluate in these strains the IC $_{50}$ values obtained by the plate-dilution technique (Reyn and others, 1963). The IC I0 $_{50}$ values for the rest of the strains ranged from 2.2 to $12.6 \mu \mathrm{g} . / \mathrm{ml}$., with nearly half at about $7 \mu \mathrm{g} . / \mathrm{ml}$., while the values for 36 of the 37 supplementary strains were from 6.3 to $10.0 \mu \mathrm{g}$. $/ \mathrm{ml}$., with half of these at about $9 \mu \mathrm{g} . / \mathrm{ml}$. Using a slightly different plate-dilution method, Pedersen and others (1972) found a MIC range from $\leqq 4.0$ to $16 \mu \mathrm{g} . / \mathrm{ml}$. with a peak at about $8 \mu \mathrm{g} . / \mathrm{ml}$. Duncan and others (1972) observed a MIC range of 5 to $15 \mu \mathrm{g} . / \mathrm{ml}$. with the majority at 10 to $15 \mu \mathrm{g}$. $/ \mathrm{ml}$. It was reported recently by Levy, Wicher, and Rose (1972) that the MIC and MBC (minimum bacteridical concentration) were very close in the sixty strains examined with Trobicin; 83 per cent. of the strains had values between 5 and $10 \mu \mathrm{g} . / \mathrm{ml}$., and the total range was from 2.5 to 20.0 $\mu \mathrm{g} . / \mathrm{ml}$. The manufacturers state that 'most strains have minimum inhibitory concentrations of 7.5 to $15 \mu \mathrm{g} . / \mathrm{ml} . '$. Thus the peak of $\mathrm{IC}_{50}$ values found in the present study was at the same level as that of the MIC found by others, the $\mathrm{IC}_{50}$ values corresponding to the killing of about 90 per cent. of the inoculum only. The different media used may explain the slightly different results.

Neither Pedersen and others (1972) nor Duncan and others (1972) observed any significant difference between the distribution of MICs in pre-treatment isolates from patients not cured by spectinomycin and in those who responded to treatment.

Both groups of workers found a positive correlation between the inhibitory values of penicillin and those of spectinomycin. A weak positive correlation between the inhibitory values of penicillin and Trobicin was also found in the present study. However, the three strains resistant to Trobicin (two post-treatment isolates and one random strain) were very sensitive to penicillin. In the supplementary series of strains less sensitive to penicillin, the inhibitory values of Trobicin were fairly narrowly distributed.

In spite of the positive correlation observed between Trobicin and penicillin sensitivity and the fact that resistant strains do occur, it is concluded that spectinomycin can be considered as a valuable alternative to penicillin and other drugs used in the treatment of gonorrhoea. It is unlikely that patients harbouring strains less sensitive to penicillin will be more difficult to cure with Trobicin than those infected with strains sensitive to penicillin.

\section{Summary}

113 patients ( 52 females and 61 males) with gonorrhoea were treated with spectinomycin hydrochloride (Trobicin), $2 \mathrm{~g}$. intramuscularly in males and $4 \mathrm{~g}$. intramuscularly in females. Four patients defaulted and there was only one failure among the remaining 109 cases.

Before treatment, the sensitivity of the gonococcal strains to Trobicin was determined by a platedilution method. The 50 per cent. inhibitory concentrations ( $\mathrm{IC}_{50}$ values) ranged from 2.2 to $12.6 \mu \mathrm{g} . / \mathrm{ml}$. in the strains derived from the patients treated with Trobicin. Nearly half of the values were about $7 \mu \mathrm{g} . / \mathrm{ml}$. In a supplementary series of 37 strains less sensitive to penicillin, the $\mathrm{IC}_{50}$ values ranged from 6.3 to $10.0 \mu \mathrm{g} . / \mathrm{ml}$. in 36 with half at $9 \mu \mathrm{g} . / \mathrm{ml}$.

Two post-treatment isolates from the patient who was not cured and one random strain were 
resistant to more than $480 \mu \mathrm{g} . / \mathrm{ml}$. of Trobicin. All three strains were sensitive to penicillin, streptomycin, and tetracycline.

In spite of a positive correlation between the $\mathrm{IC}_{50}$ values of penicillin and Trobicin, it is concluded that spectinomycin may be considered as a valuable alternative to penicillin in the treatment of gonorrhoea. The relatively narrow range of $\mathrm{IC}_{50}$ values of Trobicin did not permit us to decide on the identity of strains between sexual partners.

Gonococcal strains isolated in Odense, Funen, were generally more sensitive to penicillin, tetracycline, and streptomycin than those from the whole of Denmark.

\section{References}

Cornelius, C. E., and Domescik, G. (1970) Brit. J. vener. Dis., 46, 212

Duncan, W. C., Holder, W. R., Roberts, D. P., and Knox, J. M. (1972) Antimicrob. Agents and Chemother., 1, 210

Epstein, E. (1959) F. Amer. med. Ass., 169, 1055

Labowitz, R., Porter, W. L., and Holloway, W. J. (1970) Delaware med. F., 42, 353

LAIRD, S. M., and TAYLOR, G. (1962) Brit. F. vener. Dis., 38, 60

LeVy, J., Wicher, K., and Rose, N. R. (1972) 'Susceptibility of Neisseria gonorrhoeae to spectinomycin'. Abstracts Ann. Meeting Amer. Soc. Microbiol. M35, Philadelphia, Pa. 23-28 April 1972.

Pedersen, A. H. B., Wiesner, P. J., Holmes, K. K., JohNson, C. J., and Turck, M. (1972) f. Amer. med. Ass., 220, 205

Platts, W. M. (1970) Med. F. Aust., 2, 500

REYN, A. (1961) Brit. F. vener. Dis., 37, 145

— (1963) Acta derm.-venereol. (Stockh.), 43, 380

- and Bentzon, M. W. (1963) Ibid., 43, 394

- - , and ERICsson, H. (1963) Acta path. microbiol. scand., 57, 235

-, Korner, B., and Bentzon, M. W. (1958) Brit. $\mathcal{F}$. vener. Dis., 34, 227

$\longrightarrow,-,-$ (1960) Ibid., 36, 243

RINGERTZ, O. (1960) Acta path. microbiol. scand., 48, 106

SCHMIDT, H. (1961) Ugeskr. Laeg., 123, 749

and LARSEN, S. O. (1962) Acta derm.-venereol. (Stockh.) 42, 294

- Roholt, K., and Larsen, S. O. (1967) Acta path. microbiol. scand., 71, 603
SCHROETER, A. L., and LuCAS, J. B. (1972) Obstet. and Gynec., 39, 274

Sparling, P. F., Yobs, A. R., Billings, T. E., and HACKNEY, J. F. (1966) 'Antimicrobial Agents and Chemotherapy 1965 , p. 689

Tiedemann, J. H., Hackney, J. F., and Price, E. V. (1965) F. Amer. med. Ass., 191, 89

WILLCox, R. R. (1959) Med. Wld (Lond.), 90, 123

- (1963) Acta derm.-venereol. (Stockh.), 43, 399

Le chlorhydrate de spectinomycine (Trobicine) dans le traitement de la gonococcie. Observation de souches résistantes de Neisseria gonorrhoeae

SOMMAIRE

113 malades (52 femmes et 61 hommes) atteints de gonococcie furent traités par le chlorhydrate de spectinomycine (Trobicine) intra-musculaire: $2 \mathrm{~g}$ chez l'homme, $4 \mathrm{~g}$ chez la femme. Quatre malades ne se présentèrent pas pour le contrôle et il n'y eut qu'un échec parmi les 109 autres.

Avant traitement, la sensibilité des souches de gonocoques à la Trobicine fut déterminée par la méthode des dilutions en plaques. La concentration 50 pour cent inhibitrice (valeur $\mathrm{IC}_{50}$ ) varia de 2,2 à $12,6 \mu \mathrm{g} / \mathrm{ml}$ pour les souches provenant des malades traités par la Trobicine; pour presque la moitié des souches, les valeurs se situèrent aux environ de $7 \mu \mathrm{g} / \mathrm{ml}$. Pour une série supplémentaire de 37 souches moins sensibles à la pénicilline, les valeurs $\mathrm{IC}_{50}$ varièrent de $6,3 \mathrm{à} 10,0 \mu \mathrm{g} / \mathrm{ml}$ pour 36 , avec, pour la moitié, un chiffre de $9 \mu \mathrm{g} / \mathrm{ml}$.

Deux isolements post-thérapeutiques chez des malades non guéris, et une souche prise au hasard, furent résistants à plus de $480 \mu \mathrm{g} / \mathrm{ml}$ de Trobicine. Toutes les souches furent sensibles à pénicilline, streptomycine et tétracycline.

Bien qu'il y ait corrélation entre les valeurs $\mathrm{IC}_{50}$ pour la pénicilline et la Trobicine, on conclut que la spectinomycine peut être considérée comme capable de remplacer la pénicilline dans le traitement de la gonococcie.

La marge relativement étroite des valeurs IC $_{50}$ pour la Trobicine ne nous a pas permis de prendre parti sur l'identité des souches des partenaires sexuels.

Les souches de gonocoques isolées à Odense, Funen, furent généralement moins sensibles à pénicilline, tétracycline et spectinomycine que celles de l'ensemble du Danemark. 